Contents lists available at http://ejournal.uin-suska.ac.id

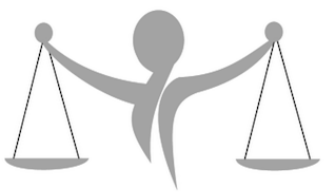

Al-Ittizaan: Jurnal Bimbingan Konseling Islam

ISSN: $2620-3820$

Journal homepage: http://ejournal.uin-suska.ac.id/index.php/alittizaan

\title{
Layanan Konsultasi Kasus Anak Korban Kekerasan Fisik Di Pusat Pelayanan Terpadu Pemberdayaan Perempuan Dan Anak (P2tp2a) Kota Pekanbaru
}

\author{
Rahmad Rahmad ${ }^{1}$, \\ ${ }^{1}$ Universitas Islam Negeri Sultan Syarif Kasim Riau
}

\begin{tabular}{l}
\hline Article Info \\
Article history: \\
Received September $12^{\text {th }}, 2019$ \\
Revised Oktober $10^{\text {th }}, 2019$ \\
Accepted Oktober $30^{\text {th }}, 2019$ \\
\hline
\end{tabular}

\section{Keyword:}

Layanan Konsultasi, Anak Korban Kekerasan Fisik

\begin{abstract}
Anak merupakan amanah dan anugrah dari Allah SWT yang perlu dilindungi. Anak dinilai rentan terhadap tindakan kekerasan dan penganiayaan, seharusnya di rawat, di asuh, di didik dengan baik agar mereka tumbuh dan berkembang secara sehat. Tindak kekerasan merupakan pelanggaran Hak Asasi Manusia (HAM) pelanggaran ketentuan hukum negara dan norma agama serta norma sosial (budaya dan peradaban) manusia. Untuk penanganan permasalahan anak korban kekerasan telah di bentuk Pusat Pelayanan Terpadu Perlindungan Perempuan dan Anak (P2TP2A). Berdasarkan laporan kasus korban kekerasan fisik yang terjadi di salah satu perguruan tinggi negeri yang saat ini dibantu dan mendapatkan dampingan oleh konselor, maka dapat disimpulkan bahwa konselor berupaya dengan sekuat pikiran dan tenaga memberikan pelayanan kepada korban dengan rincian kegiatan sebagai berikut 1) Konselor membuat perencanaan layanan konsultasi terdahulu. Rencana yang dibuat oleh konselor tersebut didasari oleh kebutuhan. 2) Konselor melaksanakan layanan konsultasi berdasarkan standar operasional prosedur dan di mulai dari tata cara penerimaan klien, melakukan interaksi malalui tatap muka langsung atau face to face dan melalui media telepon, empati, ramah dan terbuka serta memberikan penguatan psikologis, pengetahuan dan keterampilan sehingga konsulti merasa nyaman, terlindungi dan memiliki wawasan yang baru. 3) Melakukan evaluasi layanan konsultasi untuk mengetahui bagaimana proses, tepat atau tidaknya layanan yang diberikan atau perkembangan sikap dan perilaku atau tingkat ketercapaian tugastugas perkembangan. Secara umum aspek yang dievaluasi meliputi: kesesuaian pelaksanaan layanan, serta hambatan-hambatan yang dijumpai, dampak psikologis terhadap klien, dan respon klien, serta perubahan perkembangan klien secara pribadi dan sosialnya. 4) Setelah mengevaluasi layanan konsultasi, Selanjutnya konselor menafsirkan hasil evaluasi. Analis layanan konsultasi berkaitan dengan diri klien dalam hal ini adalah korban. Analisis hasil evaluasi yang dilakukan konselor berupa hasil konsultasi tersebut mempunyai dampak terhadap perkembangan sikap konsulti hari demi hari maupun pihak ketiga adakah perubahan positif dari tingkahlaku sebelumnya.
\end{abstract}

\section{Author:}

Rahmad Rahmad

Universitas Islam Negeri Sultan Syarif Kasim Riau

Email: Rahmad@uin-suska.ac.id 


\section{Pendahuluan}

\section{A. Analisis Situasi}

Kasus kekerasan fisik merupakan masalah serius untuk diungkapkan dan harus mendapat perhatian semua pihak. Namun realitanya masih banyak kasus-kasus kekerasan fisik dan kasus dalam rumah tangga (KDRT) yang masih belum bisa terungkap kepermukaan, khususnya yang terjadi pada anak. Hal ini disebabkan oleh berbagai faktor diantaranya adalah dari takut kepada pelaku, malu jika aib keluarga diketahui oleh publik atau budaya permissive yang memaafkan pelaku. Sejalan pemerintah mengeluarkan undang-undang No.23 tahun 2004 tentang penghapusan Kekerasan Dalam Rumah Tangga. Namun hal ini belum efektif untuk menekan jumlah angka kekerasan yang terjadi dalam rumah tangga.

Kekerasan fisik dan kekerasan dalam rumah tangga (KDRT) kebanyakan menimpa kaum anak dan perempuan yang kedudukannya dianggap rendah dan lemah dalam rumah tangga. Kekerasan yang terjadi diduga dipenuhi dengan berbagai masalah-masalah seperti masalah ekonomi yang sangat rendah yang berdampak terhadap pemenuhan kebutuhan, komunikasi yang terhambat yang mengakibatkan perselisihan paham, pengetahuan yang rendah dalam menata keluarga yang sakinah, mawaddah dan warohmah yang berujung pada tindakan destruktif dan perceraian, serta faktor lain sebagainya. Padahal dalam alquran (AtTahrim/66:6) Allah SWT berfirman:

Artinya : Hai orang-orang yang beriman, peliharalah dirimu dan keluargamu dari api neraka yang bahan bakarnya adalah manusia dan batu; penjaganya malaikat-malaikat yang kasar, keras, dan tidak mendurhakai Allah terhadap apa yang diperintahkan-Nya kepada mereka dan selalu mengerjakan apa yang diperintahkan.

Data yang diperoleh dari Dinas Pemberdayaan Perempuan dan Perlindungan Anak Provinsi Riau, pada tahun 2016 terhitung sampai bulan Juni 2016, kasus kekerasan pada anak dan perempuan mengalami peningkatan dari tahun-tahun sebelumnya. Menurut Kepala Dinas Pemberdayaan Perempuan dan Perlindungan Anak Provinsi Riau saat ditemui penulis mengatakan "Advokasi dan sosialisasi perlindungan perempuan (PP) dan perlindungan anak (PA) terus dilakukan dan terjadi peningkatan yang signifikan dari tahun ke tahun kasus kekerasan yang terjadi di berbagai daerah di Riau semakin meningkat, tahun 2014 sebanyak 361 kasus, tahun 2015 sebanyak 475 kasus, dan pada tahun 2016 terhitung sampai bulan juni sebanyak 290 kasus".

\section{B. Identifikasi dan Perumusan Masalah}

Berdasarkan latar belakang masalah diatas, maka dapat dirumuskan permasalahan bagaimana Layanan Konsultasi Kasus Anak Korban Kekeranan Fisik di Pusat Pelayanan Terpadu Pemberdayaan Perempuan dan Anak (P2TP2A) Kota Pekanbaru.

\section{Tujuan Penulisan}

Adapun tujuan yang ingin dicapai adalah untuk mengetahui bagaimana membantu Pusat Pelayanan Terpadu Pemberdayaan Perempuan dan Anak (P2TP2A) Kota Pekanbaru dalam melaksanakan layanan konsultasi terhadap kasus korban kekerasan fisik.

\section{Manfaat Kegiatan}

Manfaat yang ingin diperoleh secara teoritis dapat memberikan sumbangan yang positif bagi pengembangan ilmu pengetahuan dalam bidang bimbingan konseling khususnya pada konsentrasi konseling keluarga. 
Sementara kegunaan praktisnya bagi dosen dan konselor adalah dapat menambah wawasan dan pengetahuan dalam mengaplikasikan layanan konsultasi dengan baik, terarah dan profesional.

\section{E. Keterkaitan}

Pusat Pelayanan Terpadu Pemberdayaan Perempuan dan Anak (P2TP2A) Kota Pekanbaru merupakan stakeholders/ mitra bagi Jurusan Bimbingan Konseling Islam Fakultas Dakwah dan Komunikasi UIN Suska Riau, diantaranya menyalurkan mahasiswa untuk magang atau PKL. Kerjasama ini terselenggara akibat kebutuhan minimnya tenaga sukarela seperti konselor, psikolog dan terapis di P2TP2A Koa Pekanbaru.

\section{F. Kajian Teori}

\section{Layanan Konsultasi}

Konsultasi adalah proses membantu klien melalui pihak ketiga atau membantu sistem memperbaiki layanannya terhadap klien mereka (Robert, 2012). Layanan konsultasi merupakan bantuan individu dalam memperoleh wawasan, dan pemahaman dan cara yang diperlukan untuk menangani masalah pihak ketiga. Bantuan yang diberikan untuk memandirikan konseli agar dapat menghadapi pihak konseli ketiga yang dipermasalahkannya (Tohirin, 2008).

Menurut Tohirin bahwa konsultasi pada dasarnya dilaksanakan secara perorangan dalam format tatap muka antara guru pembimbing atau konselor dengan peserta didik (Tohirin, 2008). Dalam Layanan konsultasi, ada tiga pihak yang tidak bisa dipisahkan yaitu guru pembimbing atau konselor, konsulti dan pihak ketiga. Guru pembimbing atau konselor merupakan tenaga ahli konseling (tenaga professional) yang memiliki kewenangan melakukan pelayanan konseling sesuai dengan bidang tugasnya, konsulti adalah individu yang meminta bantuan kepada guru pembimbing atau konselor agar dirinya mampu menangani kondisi atau masalah yang dialami oleh pihak ketiga yang setidak-tidaknya sebagian menjadi tanggung jawabnya, sedangkan pihak ketiga adalah individu-individu yang kondisi atau permasalahannya di persoalkan oleh konsulti.

Untuk lebih rinci tahap-tahap dalam proses pelaksanaan layanan konsultasi adalah sebagai berikut (dalam skripsi Maryati Reni, 2010):

1. Perencanaan.

a. Mengidentifikasi konsulti.

b. Mengatur pertemuan.

c. Menetapkan fasilitas layanan.

d. Menyiapkan kelengkapan administrasi (Maryati, 2010).

2. Pelaksanaan.

a. Menerima konsulti.

b. Menyelenggarakan perstruturan konsultasi.

c. Membahas masalah yang dibawa konsulti berkenaan dengan pihak ketiga.

d. Mendorong dan melatih konsulti untuk mampu menangani masalah yang dialami pihak ketiga dan memfaatkan sumber-sumber yang ada

e. Membina komitmen konsulti untuk menangani masalah pihak ketiga dengan bahasa dan cara-cara konseling.

f. Melakukan penilaian segera.

3. Evaluasi, yaitu melakukan evaluasi jangka pendek tentang keterlaksanaan hasil konsultasi. 
4. Analisis hasil evaluasi; merupakan menafsirkan hasil evaluasi dalam kaitannya dengan diri pihak ketiga dan konsultasi sendiri.

5. Tindak lanjut merupakan konsultasi lanjutan dengan konsulti untuk membicarakan hasil evaluasi serta menentukan arah dan kegiatan lebih lanjut.

6. Laporan, pada bagian ini membicarakan dengan konsulti tentang laporan yang di perlukan oleh konsulti dan mendokumentasikan laporan layanan konsultasi (Maryati, 2010).

\section{Model-model Konsultasi}

Meningkatnya popularitas dan permintaan terhadap layanan konsultasi telah mengarah kepada pengembangan atau pengidentifikasian model atau gaya mana yang paling tepat untuk proses konsultasi.

Model historis tradisional yang menekankan proses konsultasi paling dasar adalah model yang disarankan Tharp dan Wetzel. Di dalam model ini, layanan konsultasi ditawarkan secara langsung lewat sebuah perantara menuju klien target (Robert, 2012) .

\section{Gambar 1 Model Historis Tradisional}

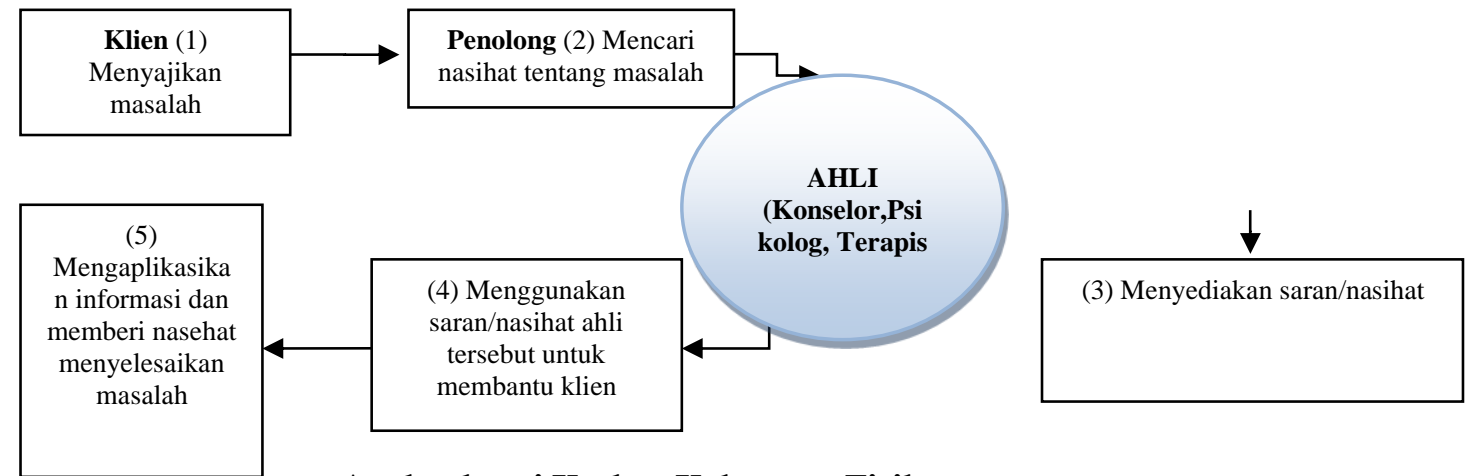

3. Tinjauan tentang Anak sebagai Korban Kekerasan Fisik

a. Faktor penyebab Tindak Kekerasan

Banyak faktor penyebab kekerasan terhadap anak. Selain faktor ekonomi, disfungsi keluarga, obsesi disorder, obsesi orangtua yang berlebihan, juga adanya nilai bahwa anak adalah hak milik orangtua yang biasa diperlakukan dengan sehendak hatinya.

Dikalangan menengah ke bawah, kekerasan terhadap perempuan dan anak pemicunya adalah karena faktor kemiskinan atau ekonomi. Dikalangan menegah ke atas, karena ambisi orangtua untuk menjadikan anaknya sesuai dengan pemikiran dan harapannya. Dan jika anak tidak menuruti perintah orangtua anak akan dianggap bandel, melawan dan bahkan dicap durhaka kepada orangtua.

Hal ini dikarenakan anak dianggap lemah, dan kebanyakan orangtua menganggap anak tidak memiliki hak dasar mereka. Dan $80 \%$ perilaku perilaku kekerasan anak dilakukan oleh perempuan, dan itu akibat dari kekerasan dalam rumah tangga yang dilakukan oleh suaminya atau karena disfungsi keluarga sehingga mereka melampiaskan emosinya dengan anak-anak (Sarwendah, 2012) .

b. Macam-macam Tindak Kekerasan

Adapun tindak kekerasan terhadap anakyang dikutip Abu Huraerah, antara lain sebagai berikut; a) Kekerasan fisik. Misalnya, dengan dipukul dengan tendangan, atau bahkan disudut rokok dan ada juga yang ditempeleng. b) Kekerasan psikologis. Misalnya dengan ancaman. c) Kekerasan seksual. Misalnya dengan memaksa untuk melakukan hubungan seksual (Huraerah, 2006). 


\section{G. Kerangka Berpikir.}

Penulis menganalisis kekuatan yang dimiliki konselor dalam memberikan layanan konsultasi, hambatan yang dihadapi dalam konsultasi, peluang yang dimiliki konselor dan tantangan dalam melaksanakan konsultasi. Secara konseptual untuk melaksanakan layanan konsultasi dibutuhkan ahli yaitu konselor, psikolog, atau terapis sebagai pihak pertama, dan konsulti sebagai pihak kedua dalam membantu memecahkan masalah klien sebagai pihak ketiga yang sedang mengalami masalah kekerasan dalam rumah tangga.

\section{H. Kerangka Pemecahan Masalah}

Dalam kegiatan ini, secara emprik peran dan tugas konselor yaitu mengungkap, menganalisis masalah perilaku-perilaku menyimpang akibat kekerasan fisik yang disampaikan konsulti dan memberikan saran atau nasihat agar konsulti dan mengentaskan persoalan klien dan memperoleh kehidupan yang efektif.

\section{Kelompok Sasaran antara yang Strategis}

Adapun kelompok sasaran dalam pengabdian ini adalah:

1. Konsulti atau pihak-pihak yang melaporkan kasus anak korban kekerasan fisik di Pusat Pelayanan Terpadu Pemberdayaan Perempuan dan Anak (P2TP2A) Kota Pekanbaru.

2. Klien korban kekerasan fisik di Pusat Pelayanan Terpadu Pemberdayaan Perempuan dan Anak (P2TP2A) Kota Pekanbaru.

\section{Metode Penelitian}

Layanan konsultasi merupakan bantuan individu dalam memperoleh wawasan, dan pemahaman dan cara yang diperlukan untuk menangani masalah pihak ketiga. Bantuan yang diberikan untuk memandirikan konseli agar dapat menghadapi pihak ketiga yang dipermasalahkannya (Ertiati, 2012). Dalam kegiatan pengabdian ini, diarahkan kepada upaya pengentasan masalah klien terkait kasus kekerasan fisik. Adapun metode pelaksanaannya adalah sebagai berikut:

a. Perencanaan.(meliputi mengidentifikasi konsulti, mengatur pertemuan, menetapkan fasilitas layanan, menyiapkan kelengkapan administrasi)

b. Pelaksanaan. (Menerima konsulti, menyelenggarakan perstruturan konsultasi, membahas masalah yang dibawa konsulti berkenaan dengan pihak ketiga, mendorong dan melatih konsulti untuk mampu menangani masalah yang dialami pihak ketiga dan memfaatkan sumber-sumber yang ada, membina komitmen konsulti untuk menangani masalah pihak ketiga dengan bahasa dan cara-cara konseling, melakukan penilaian segera)

c. Evaluasi; yaitu melakukan evaluasi jangka pendek tentang keterlaksanaan hasil konsultasi.

d. Analisis hasil evaluasi; merupakan menafsirkan hasil evaluasi dalam kaitannya dengan diri pihak ketiga dan konsultasi sendiri.

e. Tindak lanjut; merupakan konsultasi lanjutan dengan konsulti untuk membicarakan hasil evaluasi serta menentukan arah dan kegiatan lebih lanjut.

\section{Rancangan Kegiatan}

Kegiatan dilaksanakan J1. Sudirman Kecamatan Sukajadi Pekanbaru tepatnya di belakang masjid Ar-

Rahman Kota Pekanbaru. Adapun waktu pelaksanaan sesuai dengan jadwal PPkM yang diterbitkan oleh

LPPM UIN Suska Riau. Namun estimasi waktu penyelenggaraannya adalah dari bulan Juni sampai dengan Oktober Tahun 2017. 
Untuk mengukur keberhasilan kegiatan, penulis menggunakan tiga jenis penilaian dalam konseling yaitu (1) Penilaian Segera/ Laiseg, (2) Penilaian Jangka Pendek/ Laijapen, dan (3) Penilaian Jangka Panjang/ Laijapang. Hal ini merupakan treatment atau upaya konselor dalam mengentaskan persoalan klien dan memperoleh kehidupan sehari-hari yang efektif.

\section{Hasil dan Pembahasan}

Dalam upaya menanggulangi tindak kekerasan dalam rumah tangga, pada tanggal 22 September 2004, Pemerintah dan DPR RI telah mensahkan UU No 23 Tahun 2004 tentang penghapusan Kekerasan Dalam Rumah Tangga. Undang-undang itu mengatur tentang upaya pencegahan dan penanganan baik represif, kuratif maupun rehabilitas terhadap pelaku dan korban yang harus dilakukan oleh pemerintah dan masyarakat. untuk memberikan informasi dalam upaya untuk meningkatkan pemahaman dan penyadaran kepada masyarakat, maka perlu dilakukan sosialisasi yang sistematis, terarah, dan bisa menjangkau khalayak yang lebih luas dengan menggunakan berbagai metode dan pendekatan agar sampai pada sasaran.

Pembentukan P2TP2A Kota Pekanbaru di bawah koordinasi Badan Pemberdayaan Perempuan Masyarakat dan Keluarga Berencana yang kegiatannya meliputi: 1) Penanganan pengaduan, 2) Pelayanan kesehatan, 3) Rehabilitasi sosial, 4) Penegakan dan bantuan hukum, 5) Pelayanan pemulangan dan reintegrasi sosial, 6) Rumah aman (shelter) melalui rujukan secara gratis yang bepedoman pada peraturan perundangan dan Standar Pelayanan Minimal (SPM) Bidang Layanan Terpadu bagi Perempuan dan Anak korban kekerasan, dan sudah disahkan melalui Peraturan Menteri Negara Pemberdayaan Perempuan dan Perlindungan Anak No. 1 Tahun 2010, sebagai tindak lanjut Peraturan Pemerintah No. 38 Tahun 2007.

P2TP2A merupakan pusat kegiatan terpadu yang menyediakan pelayanan bagi perempuan dan anak korban kekerasan di Kota Pekanbaru yang meliputi Pelayanan Informasi, Konsultasi Psikologi dan Hukum, serta Pendamping. Sesuai dengan visinya, keberadaan P2TP2A Kota Pekanbaru mewujudkan perempuan dan anak di Kota Pekanbaru sebagai warga Negara yang bersahabat dan terhormat sesuai dengan Hak Asusila Manusia. Untuk mewujudkan visinya P2TP2A Kota Pekanbaru mempunyai misi: 1) Memberikan pelayanan yang meliputi informasi, pelayanan, pendamping pskologis dan advokasi hukum terhadap perempuan dan anak. 2) Membangun gerakan bersama untuk mencegah, menghapus, kekerasan dan traffiking terhadap perempuan dan anak. 3) Sebagai basis pemberdayaan perempuan dan anak secara Preventif, Kuratif, Rehabilitatif dan Promotif.

\section{Dasar Hukum Penyelenggaraan P2TP2A}

1. Undang-undang Nomor 23 Tahun 2002 tentang perlindungan anak (Lembaran Negara Republik Indonesia Tahun 2002 Nomor 109, Tambahan Lembaran Negara Republik Indonesia Nomor 4235)

2. Undang-undang Nomor 23 Tahun 2004 tentang penghapusan kekerasan dalam rumah tangga (Lembaran Negara Republik Indonesia Tahun 2004 Nomor 95, Tambahan Lembaran Negara Republik Indonesia Nomor 4419)

3. Undang-undang Nomor 32 Tahun 2004 tentang Pemerintah Daerah (Lembaran Negara Republik Indonesia Tahun 2004 Nomor 125, Tambahan Lembaran Negara Republik Indonesia Nomor 4437) sebagaimana telah di ubag beberapa kali, terakhir dengan Undang-undang Nomor 12 Tahun 2008 tentang perubahan kedua atas Undang-undang Nomor 32 Tahun 2004 tentang Pemerintah Daerah (Lembaran Negara Republik Indonesia Tahun 2008 Nomor 59, Tambahan Lembaran Negara Republik Indonesia Nomor 4844). 
4. Undang-undang Nomor 13 Tahun 2006 tentang Perlindungan Saksi Korban (Lembaran Negara Republik Indonesia Tahun 2006 Nomor 64, Tambahan Lembaran Negara Republik Indonesia Nomor 4635)

5. Undang-undang Nomor 21 Tahun 2007 tentang Pemberantasan Tindak Pidana Perdagangan Orang (Lembaran Negara Republik Indonesia Tahun 2007 Nomor 58, Tambahan Lembaran Negara Republik Indonesia Nomor 4720).

6. Undang-undang Nomor 44 Tahun 2008 tentang Pornografi (Lembaran Negara Republik Indonesia Tahun 2008 Nomor 181, Tambahan Lembaran Negara Republik Indonesia Nomor 4928).

7. Undang-undang Nomor 11 Tahun 2009 tentang Kesejahteraan Sosial (Lembaran Negara Republik Indonesia Tahun 2009 Nomor 12, Tambahan Lembaran Negara Republik Indonesia Nomor 4967)

8. Undang-undang Nomor 25 Tahun 2009 tentan Pelayanan Publik (Lembaran Negara Republik Indonesia Tahun 2009 Nomor 112, Tambahan Lembaran Negara Republik Indonesia Nomor 5038)

9. Undang-undang Nomor 36 Tahun 2009 tentang Kesehatan (Lembaran Negara Republik Indonesia Tahun 2009 Nomor 144, Tambahan Lembaran Negara Republik Indonesia Nomor 5063)

10. Peraturan Pemerintah Nomor 65 Tahun 2005 tentang Pedoman Penyusunan dan Penerapan Standar Pelayanan Minimal (Lembaran Negara Republik Indonesia Tahun 2005 Nomor 150, Tambahan Lembaran Negara Republik Indonesia Nomor 4585).

TABEL 1

Data Kasus Yang Ditangani Oleh P2TP2A

Kota Pekanbaru Tahun 2014 s/d 2016

\begin{tabular}{|c|c|c|c|c|c|}
\hline \multirow{2}{*}{ No } & \multirow{2}{*}{ Jenis Kasus } & \multicolumn{3}{|c|}{ Tahun } & \multirow{2}{*}{ Jumlah } \\
\hline & & 2014 & 2015 & 2016 & \\
\hline (1) & (2) & (3) & (4) & (5) & (6) \\
\hline 1 & KDRT & 13 & 15 & 11 & 39 \\
\hline 2 & Kejahatan Seksual & 4 & 14 & 1 & 19 \\
\hline 3 & Hak Asuh Anak & 12 & 10 & 5 & 27 \\
\hline 4 & $\mathrm{ABH}$ & 8 & 2 & 0 & 10 \\
\hline 5 & Penganiayaan & 0 & 3 & 3 & 6 \\
\hline 6 & Anak Hilang & 0 & 0 & 0 & 0 \\
\hline 7 & Trafficking & 0 & 10 & 3 & 13 \\
\hline 8 & Kekerasan Psikis & 0 & 0 & 0 & 0 \\
\hline 9 & Kasus Pendidikan Anak & 0 & 0 & 0 & 0 \\
\hline 10 & Kekerasan Fisik & 0 & 0 & 0 & 0 \\
\hline 11 & Pidana Murni & 0 & 0 & 0 & 0 \\
\hline 12 & Kenakalan Remaja & 0 & 1 & 6 & 7 \\
\hline 13 & Penelantaran Tenaga Kerja & 0 & 0 & 0 & 0 \\
\hline 14 & Pencemaran Nama Baik & 0 & 0 & 0 & 0 \\
\hline 15 & Menuntut Perjanjian & 0 & 0 & 0 & 0 \\
\hline 16 & Narkoba & 0 & 0 & 0 & 0 \\
\hline 17 & Pelanggaran HAM & 0 & 0 & 0 & 0 \\
\hline 18 & Intimidasi Terhadap Anak & 1 & 0 & 0 & 1 \\
\hline
\end{tabular}




\begin{tabular}{|c|c|c|c|c|c|}
\hline 19 & Hak Anak & 4 & 8 & 7 & 19 \\
\hline 20 & Penculikan & 0 & 1 & 0 & 1 \\
\hline 21 & Penipuan & 1 & 0 & 0 & 1 \\
\hline 22 & Penelantaran & 9 & 5 & 4 & 18 \\
\hline 23 & Pencabulan & 4 & 15 & 12 & 31 \\
\hline 24 & Kekerasan Terhadap Anak & 2 & 4 & 2 & 8 \\
\hline 25 & Perkosaan & 3 & 4 & 2 & 9 \\
\hline 26 & Mal Praktek & 1 & 0 & 0 & 1 \\
\hline 27 & Melarikan Anak & 0 & 4 & 0 & 4 \\
\hline 28 & Eksploitasi Anak & 0 & 0 & 1 & 1 \\
\hline \multicolumn{2}{|c|}{ Jumlah } & 62 & 96 & 57 & 215 \\
\hline
\end{tabular}

Sumber: Data P2TP2A Kota Pekanbaru Tahun 2017

Catatan :

1. Kasus Tahun 2016 sampai dengan bulan September

2. Kasus Perempuan : 61 Kasus (data 2014 s/d 2016)

1. Kasus Anak : 154 Kasus (data 2014 s/d 2016)

Anak korban kekerasan fisik dalam rumah tangga membutuhkan layanan konseling, untuk mencegah dan menetralisir dampak dari kekerasan tersebut. Melalui layanan konseling diharapkan anak korban kekerasan dapat pulih pasca tindak kekerasan dan perlakuan yang tidak manusiawi. Dalam hal membantu masalah anak korban kekerasan fisik ini, layanan konsultasi merupakan upaya konselor dalam memberikan sumbangan nasehat, saran, arahan serta bimbingan agar klien dapat terbebas dari masalah yang sedang dihadapi. Layanan konsultasi dalam bimbingan konseling dipandang sebagai suatu proses menyediakan bantuan teknis dari konselor dalam mengidentifikasi dan memperbaiki masalah klien.

Pelaksanaan layanan konsultasi tersebut dapat digambarkan sebagai berikut:

\section{a. Konselor membuat perencanaan layanan.}

Dapat disampaikan bahwa dalam melaksanakan layanan, konselor membuat sebuah perencanaan atau program layanan konsultasi terdahulu. Rencana atau program yang dibuat oleh konselor tersebut didasari oleh kebutuhan. Untuk itu standart operasional prosedur telah ditetapkan oleh Pusat Pelayanan Terpadu Pemberdayaan Perempuan dan Anak (P2TP2A) Kota Pekanbaru. Setelah itu konselor mulai mengidentifikasi klien dengan melakukan pengecekan data diri dan masalah yang dilaporkan atau terdaftar di bagian administrasi kantor Pusat Pelayanan Terpadu Pemberdayaan Perempuan dan Anak Kota Pekanbaru. Jika data diri dan masalah sudah diperoleh dari klien, maka konselor dapat langsung menemui dan melaksanakan konseling. Dari segi waktu, proses konseling berlangsung sekitar 45-60 menit terhadap 1 orang klien

\section{b. Melaksanaan Layanan Konsultasi}

Konselor melaksanakan layanan konsultasi berdasarkan standar operasional prosedur Pusat Pelayanan Terpadu Pemberdayaan Perempuan dan Anak Kota Pekanbaru. Adapun tugas konselor adalah menyediakan berbagai pelayanan anak baik fisik dan non fisik, yang meliputi antara lain informasi dan data, rujukan, konsultasi/ konseling, pelatihan keterampilan, serta menyediakan sarana bagi peningkatan kualitas hidup perempuan serta kesejahteraan dan perlindungan anak, meningkatkan peran serta masyarakat dan pemangku kepentingan (stakeholder) dalam penyelenggaraan pelayanan terpadu pemberdayaan perempuan serta kesejahteraan dan perlindungan anak. 
Konselor yang membantu mengatasi kasus korban kekerasan mengetahui dan memahami secara keseluruhan bagaimana semestinya harus dilakukan. Untuk mendorong klien terbuka dalam menyampaikan permasalahannya, konselor menerapkan beberapa metode, pendekatan dan teknik-teknik dalam konseling dengan melakukan pendekatan konseling rasional emotif yang dikembangkan oleh Albert Ellis, yang memandang manusia pada dasarnya adalah unik yag memiliki kecenderungan untuk berpikir rasional \& irasional. Ketika berpikir dan bertingkahlaku rasional manusia akan efektif, bahagia, \& kompeten. Ketika berpikir \& bertingkahlaku irasional individu itu menjadi tidak efektif. Dimana tugas konselor adalah memberikan keyakinan klien yang negatif terhadap diri sendiri dan bukan mengatasi perasaan sedih \& kesepian yg dialami klien.

\section{c. Mengevaluasi Layanan Konsultasi}

Evaluasi pemberian layanan konsultasi dilakukan untuk mengetahui bagaimana proses, tepat atau tidaknya layanan yang diberikan atau perkembangan sikap dan perilaku atau tingkat ketercapaian tugas-tugas perkembangan. Secara umum aspek yang dievaluasi meliputi: kesesuaian pelaksanaan layanan, serta hambatanhambatan yang dijumpai, dampak psikologis terhadap klien, dan respon klien, serta perubahan perkembangan klien secara pribadi dan sosialnya.

\section{d. Analisis Layanan Konsultasi}

Setelah mengevaluasi layanan konsultasi, Selanjutnya konselor menafsirkan hasil evaluasi. Analis layanan konsultasi berkaitan dengan diri klien dalam hal ini adalah korban kekerasan. Analisis hasil evaluasi yang dilakukan konselor berupa sejauh mana konsultasi tersebut mempuyai pengaruh terhadap perkembangan pengetahuan dan sikap konsulti hari demi hari maupun pihak ketiga adakah perubahan positif dari tingkahlaku sebelumnya. Dengan menganalisis hasil evaluasi layanan konsultasi yang telah diberikan maka konselor akan lebih mudah memantau perkembangan apa yang terjadi dari konsulti dan pihak ketiga tersebut dan akhirnya konsultasi tersebut akan lebih efektif, kreatif dan kondusif dari pertemuan demi pertemuan.

\section{e. Tindak Lanjut Layanan Konsultasi}

Tindak lanjut layanan konsultasi diberikan terhadap klien dalam rangka untuk mengetahui perkembangan dan layanan selanjutnya. Dalam menindak lanjuti hasil evaluasi, konselor lebih aktif dalam mencermati perkembangan klien serta peduli dan empati terhadap permasalahan yang dihadapi klien. Hal ini bertujuan agar klien merakasan bahwa konselor sungguh-sungguh ingin membantu menyelesaikan persoalan yang sedang dihadapi.

\section{Kesimpulan}

Anak adalah amanah dan anugrah dari Allah SWT yang perlu dilindungi harkat dan martabatnya serta dijamin hak-haknya untuk tumbuh dan berkembang. Anak sebagai generasi penerus bangsa, selayaknya mendapatkan hak-hak dan kebutuhan-kebutuhan. Anak yang dinilai rentan terhadap tindakan kekerasan dan penganiayaan, seharusnya di rawat, di asuh, di didik dengan sebaik-baiknya agar mereka tumbuh dan berkembang secara sehat.

Tindak kekerasan merupakan pelanggaran Hak Asasi Manusia (HAM) pelanggaran ketentuan hukum negara dan norma agama serta norma sosial (budaya dan peradaban) manusia. karena itu tidak ada tindak kekerasan apalagi telah menderai fisik, melukai perasaan atau melantarkan hidup orang dapat dibenarkan dalam peradaban manusia. 
Berdasarkan laporan kasus korban kekerasan fisik yang terjadi di salah satu perguruan tinggi negeri yang saat ini dibantu dan mendapatkan dampingan oleh konselor (Rahmad, M.Pd), maka dapat disimpulkan bahwa konselor berupaya dengan sekuat pikiran dan tenaga memberikan pelayanan kepada korban dengan rincian kegiatan sebagai berikut:

1. Konselor membuat perencanaan layanan konsultasi terdahulu. Rencana yang dibuat oleh konselor tersebut didasari oleh kebutuhan.

2. Konselor melaksanakan layanan konsultasi berdasarkan standar operasional prosedur dan di mulai dari tata cara penerimaan klien, melakukan interaksi malalui tatap muka langsung atau face to face dan melalui media telepon, empati, ramah dan terbuka serta memberikan penguatan psikologis, pengetahuan dan keterampilan sehingga konsulti merasa nyaman, terlindungi dan memiliki wawasan yang baru.

3. Melakukan evaluasi layanan konsultasi untuk mengetahui bagaimana proses, tepat atau tidaknya layanan yang diberikan atau perkembangan sikap dan perilaku atau tingkat ketercapaian tugas-tugas perkembangan. Secara umum aspek yang dievaluasi meliputi: kesesuaian pelaksanaan layanan, serta hambatan-hambatan yang dijumpai, dampak psikologis terhadap klien, dan respon klien, serta perubahan perkembangan klien secara pribadi dan sosialnya.

4. Setelah mengevaluasi layanan konsultasi, Selanjutnya konselor menafsirkan hasil evaluasi. Analis layanan konsultasi berkaitan dengan diri klien dalam hal ini adalah korban kekerasan. Analisis hasil evaluasi yang dilakukan konselor berupa sejauh mana konsultasi tersebut mempuyai pengaruh terhadap perkembangan pengetahuan dan sikap konsulti hari demi hari maupun pihak ketiga adakah perubahan positif dari tingkahlaku sebelumnya.

\section{Daftar Pustaka}

Arikunto Suharsimi. 1997. Prosedur Penelitian Suatu Pendekatan Praktek. Rineka Cipta: Jakarta.

Ertiati Suhesti, Endang. 2012. Bagaimana Konselor sekolah bersikap?. Pustaka Pelajar:Yogyakarta

Huraerah Abu, 2006. Kekerasan Terhadap Anak.Jakarta:Penerbit Nuansa

J.Meleong, Lexy.2012. Metodologi Penelitian Kualitatif. Bandung: PT. Remaja Rosdakarya

Juntika Achmad Nurihsan, M.Pd. 2012. Strategi Layanan Bimbingan dan Konseling. PT. Refika Aditama:Bandung.

Muhammad Nasib ar-Rifa'i. 2000. Ringkasan tafsir Ibnu Katsir jilid 4. Jakarta:Gema Insani

Nanang Solihin. 2010.Al-Qur'anul Karim dengan tajwid akronim (singkatan). Jakarta: Lautan Lestari

Prayitno dan Erman Amti, Dasar-dasar Bimbingan dan Konseling, Jakarta: PTRineka Cipta, 2004.

Robert L. Gibson dan Marianne H. Mitchell.2012. Bimbingan dan Konseling.Pustaka Pelajar:Yogyakarta.

Dessy Irna Eka Puti.2013. Pelaksanaan Layanan Konsultasi Untuk Meningkatkan Disiplin Siswa Disekolah Menengah Atas Negeri 1 Salo Kecamatan Salo Skripsi.Fakultas TarbiyahdanKeguruan:UIN-SUSKA Riau

Maryati Reni.2010. Pelaksanaan Layanan Konsultasi oleh Guru Pembimbing Di Sekolah Menengah Atas Negeri $1 \mathrm{~K}$

ampar.Skripsi.UIN-SUSKA Riau 
Destari Ayu. 2014. Pelaksanaan Layanan Konseling Individu Dalam Membantu Anak Korban Kekerasan Seksual Di Pusat Pelayanan Terpadu Pemberdayaan Perempuan dan Anak (P2TP2A) Kota Pekanbaru. Skripsi.Fakultas dakwah dan Komunikasi:UIN SUSKA Riau

Surya Mohammad, 2003.Psikologi Konseling, Bandung: Pustaka Bani Quraisy,

Tohirin.2008. Bimbingan Dan Konseling Di Sekolah Dan Madrasah(berbasis integrasi) PT Rajagrafindo:Jakarta.

W.J.S Poerwadarminta.2007. Kamus Umum Bahasa Indonesia.Balai Pustaka:Jakarta.

Zakiah Daradjat.2010. Ilmu Jiwa Agama.Jakarta: Bulan Bintang

Zuriah Nurul. 2005. Metode Penelitian Sosial Dan Pendidikan. Jakarta: Bumi Aksara

Sarwendah Indrarani di akses dari http://psikologikita.com/?q=kekerasan-dalam-rumah-tanggaJum-06/07/2012 